\title{
JOKOWI DAN KEKUATAN PENCITRAAN DIRI SERTA RELASINYA DENGAN UMAT ISLAM
}

\author{
Alifa Nur Fitri*, Adeni \\ Universitas Islam Negeri Walisongo Semarang \\ Email: alifanurfitri89@walisongo.ac.id
}

\begin{abstract}
This article aims to discuss the image formation carried out by Jokowi in his political communication. Jokowi is a politician who was elected president for two terms. This paper uses the impression formation and impression management perspectives to analyze Jokowi's self-image construction. Using qualitative methods, this article proves that Jokowi succeeded in building his image as a humble, modest and modest leader figure. On the other hand Jokowi's image is reinforced by the impression of his closeness to Muslims. This he did in the context of himself which is often imaged as anti-Islamic.
\end{abstract}

KEYWORDS: Impression Formation, Impression Managament, J okowi..

\section{ABSTRAK}

Artikel ini bertujuan membahas tentang pembentukan citra diri yang dilakukan oleh Jokowi dalam komunikasi politiknya. Jokowi merupakan seorang politisi yang terpilih menjadi presiden selama dua periode. Makalah ini menggunakan perspektif impression formation dan impression management untuk menganalisis konstruksi citra diri oleh Jokowi. Dengan menggunakan metode kualitatif, artikel ini membuktikan bahwa Jokowi berhasil membangun citra dirinya sebagai figur pemimpin yang rendah hati, sederhana dan tidak berlebihan. Di sisi lain citra Jokowi diperkuat dengan kesan kedekatannya dengan umat Islam. Hal ini ia lakukan dalam konteks dirinya yang sering dicitrakan sebagai anti-Islam. 


\section{Pendahuluan}

Keberadaan dan kesuksesan Jokowi sebagai kepala daerah adalah sebuah fenomena tersendiri. Jokowi meniti karir dari bawah. Sebelum menjadi seorang presiden Jokowi berhasil membawa Solo ke internasional. Program-program yang dilakukan oleh Jokowi dinilai berhasil dan sukses. Kegiatan City Branding yang dilakukan dengan tema 'Spirit of Java' mampu menarik para wisatawan dari dalam dan luar negeri.

Selain itu cara pendekatan yang khas dilakukan oleh Jokowi dengan membangun hubungan interpersonal tanpa kekerasan mampu memberikan hasil yang nyata. Pemerintah Solo melalui satpol PP (Satuan Polisi Pamong Praja) mengubah cara kekerasan yang biasa dilakukan oleh Satpol PP dengan pendekatan persuasi dan sosialisasi. Hasilnya Solo mampu memindahkan pedagang kaki lima dan menertibkannya, merelokasikannya, dan menjadikan pusat wisata kuliner kaki lima. Jokowi juga pernah mendapatkan penghargaan sebagai salah satu walikota terbaik di dunia. Situs resmi World Mayor Project menyebut keberhasilannya mengubah Surakarta dari kota yang banyak tindak kriminal menjadi pusat seni dan budaya, yang kemudian berhasil menarik turis internasional untuk datang (Andylala Waluyo 2013).

Kesuksesan Jokowi membawa Solo maju pada akhirnya mengundang PDI Perjuangan untuk mencalonkannya sebagai Gubernur J akarta. Berbagai prestasi Jokowi yang diekspose oleh media akhirnya mampu mengambil hati masyarakat Jakarta. Berbagai dukungan muncul dengan berbagai gaya, dari membuat video klip kemudian baju kotak-kotak yang dikenal sebagai 'baju Jokowi.' Akhirnya Jokowi mampu menduduki kursi Gubernur DKI, mengalahkan gubernur sebelumnya, yaitu Bang Foke. Jokowi bagaikan media darling. Apa yang dilakukannya selalu disorot oleh media, program-program pro rakyatnya pun tetap dilakukan, seperti program blusukan, kartu sehat, tata kota yang baik untuk mengurangi kemacetan, dan program mengurangi banjir terus dilakukan oleh Jokowi bersama pasangannya.

Program yang diterapkannya di Jakarta ternyata juga cukup sukses. Pemerintah Jakarta bersama Jokowi mampu menertibkan Pasar Tanah Abang yang sebelumnya adalah salah satu titik kemacetan Jakarta. Keberanian J okowi 
dan Ahok merebut Blok G Pasar Tanah Abang melalui pendekatan persuasi mampu mengajak pedagang untuk direlokasi. Secara umum, kepemimpinan Jokowi mampu memberikan perubahan positif bagi masyarakat.

Keberhasilan Jokowi mengubah Jakarta membawa Jokowi untuk dicalonkan oleh Partai PDI ke kursi kepresidenan. Di tahun 2014 Jokowi memenangkan pemilihan dengan $53,15 \%$. Sampai saat ini, dari hasil pemilihan umum tahun 2019, Jokowi kembali mampu memenangkan Presiden untuk kedua kalinya. Fenomena ini menarik untuk diteliti bagaimana pengelolaan citra yang dilakukan oleh Jokowi sehingga bisa menang diberbagai pemilihan kepala daerah sampai ke presiden.
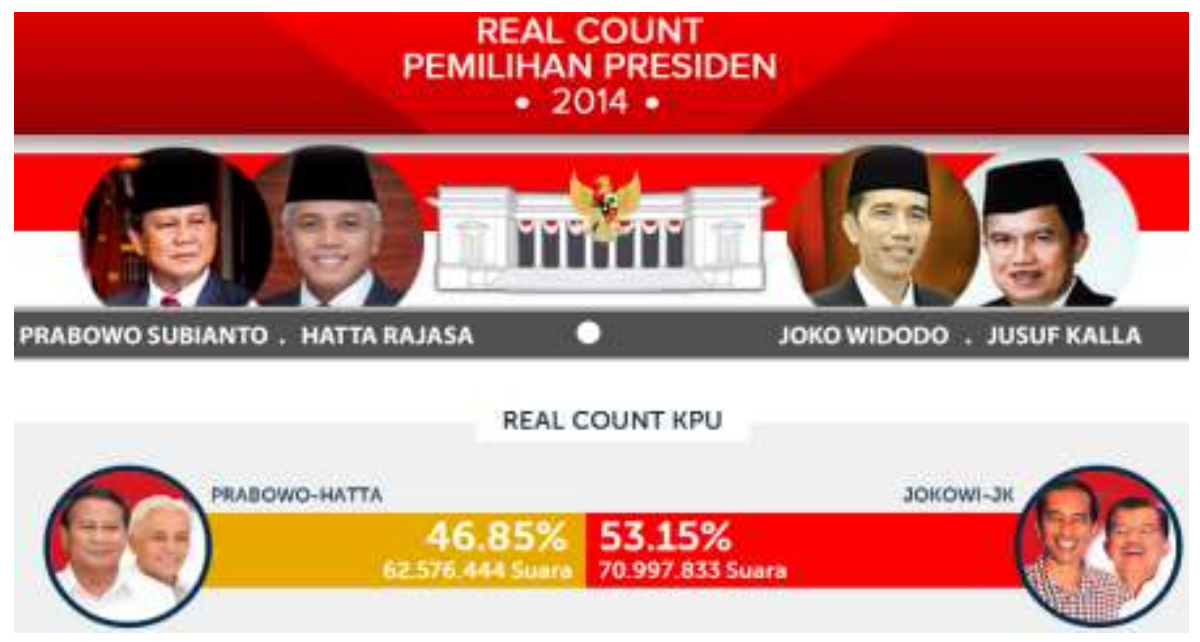

Gambar 1.1 Hasil Real Account Pemilihan Preseiden

Fakta lain, Jokowi seringkali diisukan sebagai anti-Islam. Hal ini menguat sejak bergulirnya aksi-aksi kelompok Islam di Jakarta. Terdapat dua aksi besar umat Islam di Silang Monas Jakarta, dan Jokowi dianggap tidak berpihak pada aksi tersebut. Belum lagi setelah itu, Jokowi melakukan pembubaran terhadap organisasi HTI (Hizbut Tahrir Indonesia) yang terindikasi ingin menggantikan Pancasia sebagai ideologi negara. Jarak Jokowi dengan beberapa kelompok Islam semakin terlihat lebar ketika pada pemilu 2019, Jokowi lebih banyak didukung oleh partai yang tidak berideologi Islam. Namun di sisi lain, Jokowi justru mendapat dukungan yang luar biasa dari organisasi keislaman NU (Nahdlatul Ulama) dengan terpilihnya KH. Ma'ruf Amin sebagai calon Wakil 
Presiden.

Penelitian ini bertujuan membahas bagaimana Jokowi melakukan pencitraan diri di awal kepemimpinannya serta bagaimana Jokowi membentuk kesan terhadap dirinya dan mengatur kesan yang akan ditampilkan di masyarakat sementara di sisi lain Jokowi dicitrakan sebagai seseorang yang anti dengan Islam. Jokowi dinilai berhasil melakukan kedua hal ini karena di tengah isu yang dihadapkan pada Jokowi dia bisa mempertahankan kesannya di mata masyarakat. Selain itu, J okowi dianggap sukses dalam melakukan pembentukan kesan dan pengelolaan pesan karena mampu bertahan menjadi Presiden sampai saat ini.

Metodologi yang digunakan dalam penulisan ini adalah metode kualitatif dengan menggunakan analisis deskriptif dengan bertumpu pada teori impression formation/ pembentukan kesan dan teori impression management/pengelolaan kesan yang diperkenalkan oleh Erving Goffman (1956). Penulis menggunakan Teknik simak dalam pengumpulan data penelitian data yang digunakan dalam tulisan ini diambil dari pembentukan dan pengelolaan kesan yang dilakukan Jokowi yang tersebar dalam media massa dan media sosial yang berkaitan dengan politik selama pemilihan Presiden dan masa kepemimpinannya. Data diambil dari pemberitaan media online yang ada di Indonesia seperti Tempo, Detik, Kompas dan Republika dalam memberitakan Jokowi dan relasinya dengan umat Islam.

\section{Hasil penelitian dan Pembahasan}

\section{Pembentukan Kesan Jokowi}

Ditahun 2014 geliat persaingan politik untuk mendapatkan hati rakyat sudah banyak di temukan, dengan berbagai cara dan strategi. Berbagai partai politik dan calon yang akan diusungnya mulai membentuk pencitraan, dengan tujuan agar nama mereka dan janji mereka bisa dengan mudah diingat oleh masyarakat luas. Hal inilah yang akan kita bahas lebih lanjut dalam pembahasan pencitraan. Dalam tulisan ini kesan-kesan yang dibangun oleh Jokowi akan dikaitkan dengan teori impression formation/pembentukan kesan dan teori impression management/pengelolaan kesan. 
Kata pencitraan mengalami perubahan makna. Makna sekarang mengalami penurunan nilai rasa daripada makna awalnya. Kata pencitraan seolah berkonotasi negatif. Orang yang melakukan pencitraan digambarkan seperti orang yang menggunakan topeng karena bertentangan dengan konsep 'be your self'. Mereka memilih nilai, sikap, dan menggambarkan dirinya dengan beberapa sifat yang dianggapnya baik dan akan menguntungkan dirinya.

Impresi/kesan merupakan gambaran/citra kita terhadap orang lain, yang terdiri dari keyakinan kita terhadap karakteristik orang tersebut. Karakteristik meliputi kepribadian seseorang, peran, atribut/ciri-ciri fisik, dan perilaku yang wajar/kebiasaan. Sementara pembentukan kesan adalah proses psikologis bagaimana sebuah kesan dikembangkan, yang terjadi melalui kegiatan komunikasi (Littlejohn and A. Foss 2012, 503).

Secara sederhana, kesan adalah citra kita terhadap orang lain, yang pembentukannya melalui proses komunikasi (Asch 1946). Ada beberapa istilah yang muncul seperti kesan publik. Kesan publik adalah citra atau gambaran tentang diri yang dibentuk dan dikomunikasikan secara luas bisa melalui media massa. Beberapa elit politik menggunakan hal ini, terlebih saat mendekati pemilu. Mereka menciptakan suatu citra terhadap dirinya yang kemudian dikomunikasikan melalui media massa.

Beberapa lawan politik Jokowi menciptakan kesan publik pula, untuk bersaing dan mengalahkan Jokowi. seperti Abu Rizal Bakri yang membuat iklan politik dengan berbagai tema untuk menyasar berbagai lapisan masyarakat, Gita Wiryawan dengan iklan politiknya 'berani jujur lebih baik.' Selain itu Harie Tanoe yang menggunakan medianya untuk beriklan, bukan hanya iklan yang digunakan, Harie Tanoe menggunakan soft campaign melalui kuis seperti kuis Indonesia Cerdas. Berbagai upaya dilakukan oleh lawan politik Jokowi untuk mendapatkan suara di Pemilu 2014. Jika upaya politik yang dilakukan lawan politik Jokowi tampak dalam bentuk kuliah umum, iklan politik, soft campaign dengan berita bantuan-bantuan terhadap bencana, dan lain-lain, maka J okowi melakukannya dengan tenang, tanpa perlu keliling Indonesia untuk kuliah umum, dan tanpa perlu mengeluarkan banyak dana untuk mengundang wartawan. Jokowi cukup dengan gayanya, melakukan tugasnya dengan sebaikbaiknya. 
Sosoknya sederhana. la tampil apa adanya dan dengan pembawaannya yang tenang, tetapi tegas dalam kesehariannya. Jokowi membentuk kesan bahwa dirinya adalah pemimpin yang merakyat dan selalu mementingkan kebutuhan rakyat daripada elit partainya. Untuk mendukung pembentukan kesan ini, disusunlah strategi-strategi yang akan mendukung untuk menunjukkan bahwa dirinya adalah pro rakyat, sebut saja beberapa kegiatan J okowi seperti blusukan dan pemberian kartu kesehatan untuk rakyat miskin.

Kesan yang terlihat akan dikukuhkan dalam proses komunikasi dan interaksi di dalamnya. Seseorang bisa melihat secara langsung apakah kesan yang terlihat akan sesuai dengan kesehariannya dalam berinteraksi (Carlston and Mae 2000). Dalam teori uncertainly reduction theory (teori pengurangan ketidakpastian) dijelaskan bahwa untuk mengurangi ketidakpastian seseorang bisa dikurangi dengan melakukan komunikasi dan interaksi, dari proses awal perkenalan hingga mempelajari karakteristiknya (Littlejohn 2012, 503). Charles Berger $(1982,7)$ dalam teorinya mengenai pengurangan ketidakpastian berfokus pada cara individu memperhatikan lingkungan sosial dan lebih mengenal diri mereka dan orang lain melalui interaksi. Hal ini terlihat pada saat pertama kali mengenal seseorang, kita akan menciptakan prediksi-predisksi mengenai seseorang tersebut, baik perilaku, sifat dan karakteristiknya, berisi dengan berbagai ketidakpastian. Ketika kita berkomunikasi dan berinteraksi dengan orang lain kita membuat rencana untuk mencapai tujuan kita (Griffin 2012).

Berger menyatakan ada beberapa strategi yang bisa digunakan untuk mengurangi ketidakpastian, yaitu melalui strategi pasif, strategi aktif, dan strategi interaktif. Strategi pasif yang pertama adalah reaktivitas pengamatan. Individu diamati ketika melakukan sesuatu, dan ketika bereaksi dalam situasi tertentu. Cara yang kedua dalam pengamatan pasif adalah disinhibition searching (pengamatan lepas) dengan cara mengamati orang dalam situasi informal di mana mereka kurang mengamati diri dan bersikap dalam cara yang lebih alami. Strategi aktif yaitu dengan cara menanyakan seseorang melalui orang lain atau dengan mencari tahu tentangnya melalui 'google'. Sementara strategi interaktif mencakup interogasi dan pengungkapan diri/self disclouser (Littlejohn, Stephen 2009, 219). 
Dalam pandangan masyarakat kesan yang muncul dari Jokowi akan dibuktikan ketika Jokowi berinteraksi dan berkomunikasi. Jika kesan merakyat yang sebelumnya muncul dan ketika terjadi komunikasi hal ini tidak sesuai, maka penciptaan tersebut akan hilang. Kesan itu bisa dilihat oleh lawan komunikasi kita, jika kesan yang ingin diciptakan tersebut tidak muncul ketika komunikasi terjadi maka hal ini akan hilang. Melakukan sebuah pencitraan atau penciptaan kesan ini tidaklah mudah. Jika kesan yang akan diciptakan ini tidak berasal dari dalam diri sesorang maka akan dengan susah payah melaksanakannya bahkan dengan kemungkinan tidak akan berhasil. Maka ketika akan membuat sebuah pencitraan, ambillah dari nilai positif yang memang ada dalam diri kita.

Dalam proses pembentukan kesan, skill komunikasi yang dimiliki oleh komunikator sangat menentukan keberhasilan pembentukan kesan. Sebagai seorang pengusaha, kemampuan komunikasi J okowi dinilai sangat baik. Budaya timur yang dijunjung oleh Jokowi tentang kesopanan, menghormati orang lain, dan menolong pihak yang lemah bisa terkomunikasikan dengan baik.

Selama proses interaksi di antara dua orang, pengamat membentuk kesan terhadap target terjadi dalam empat proses, yaitu pertama pengamat mengamati perilaku target, kedua pengamat menghubungkan penyebab perilaku tersebut, ketiga pengamat menginterpretasi penyebab perilaku sebagai karakteristik target sehingga pengamat membentuk kesan terhadap target; dan keempat pengamat menggunakan kesan tersebut untuk menilai target. Maka unitizing berarti membagi perilaku ke dalam unit yang bisa diukur berdasarkan pengetahuan dan tujuan kita. Setelah membagi perilaku ke dalam unit-unit yang bisa dikelola, pengamat akan memberikan label pada unit tersebut.

Masyarakat akan menggunakan keempat proses tersebut dalam pembentukan kesan terhadap Jokowi. Di tahapan pertama, yaitu masyarakat mengamati perilaku J okowi. Jokowi yang suka blusukan, memiliki keluarga yang harmonis dan apa adanya bisa diamati dari media. Media berperan penting di sini. Maka di awal kepemimpinan, Jokowi bagaikan media darling yang segala halnya diliput oleh media. Di sinilah tahapan pertama terbentu. Masyarakat mengamati perilaku Jokowi. 
Tahapan kedua adalah masyarakat menghubungkan penyebab perilaku tersebut, mereka menganalisis kenapa J okowi melakukan beberapa hal di awal kepemimpinannya seperti Blusukan dan lain-lain. Hal itu disa dikarenakan Jokowi ingin mengetahui keadaan masyarakat sekitarnya secara nyata untuk mengesankan bahwa Jokowi peduli dengan masyarakat kelas bawah dan untuk mengetahui permasalahan dalam masyarakatnya.

Tahapan ketiga adalah masyarakat menginterpretasi penyebab perilaku. Berbagai interpretasi diberikan penyebab Jokowi memilih blusukan dan merakyakat. Interpretasi ini di satu sisi berkaitan dengan latar belakang sosial Jokowi sendiri yang berasal rakyat biasa. Di sisi lain bisa jadi karena Jokowi memahami betul sosial-budaya masyarakat Indonesia yang penuh keakraban dan intimitas. Dan tahapan keempat adalah masyarakat menggunakan kesan untuk menilai Jokowi. Apa yang dilakukan Jokowi dikesankan masyarakat sebagai pemimpin yang pro rakyat dan peduli. Keempat proses itu digunakan untuk membentuk kesan dan memberikan label terhadap J okowi.

Dasar bangunan teori pembentukan kesan (impression formation) adalah Teori Kepribadian Tersirat/Implisit Personaly Theory yang menyatakan bahwa kepercayaan kita melekat pada kepribadian seseorang. Misalnya pemimpin yang baik biasanya akan mendengarkan orang lain, pandai berbicara, pintar mengambil hati orang lain, dan lain sebagainya. Konsistensi inilah yang menjadi prototipe seseorang yang disebut good leader/pemimpin yang baik. Karena prototype yang tercipta tentang pemimpin seperti ini, Jokowi telah memenuhi kriterianya. Jokowi melakukan cara kampanye yang berbeda, dia cukup menjadi pemimpin yang diinginkan, dia mampu mendengarkan apa yang masyarakat inginkan melalui program Blusukan, pintar mengambil hati orang lain baik elit politik atau oleh para pedagang kaki lima. Hal ini terbukti dari kepiawaian Jokowi untuk merelokasi para pedagang kaki lima. Kebijakan yang diciptakannyapun pro rakyat misalnya mengurangi dan memperketat pendirian mal. Jokowi dinilai berani, bahkan dia berani menentang keputusan Presiden yang dinilai kurang bijak dengan mengadakan program mobil murah karena dianggap akan menambah kemacetan Jakarta. 


\section{Pembentukan Kesan Melalui Media/Mediated}

Hasilnya ditemukan bahwa kesan yang terbentuk melalui media cenderung netral karena ketiadaan petunjuk nonverbal seperti yang terlihat pada komunikasi face-to-face/tatap muka. Hasil ini menjadi dasar usulan pada penciptaan teori Kekayaan Media/Media Richness, yang menjelaskan ketidakmampuan membentuk kesan yang kaya melalui interaksi menggunakan media/bermedia. Maka, memungkinkan proses pembentukan kesan berlangsung seperti halnya komunikasi tatap muka dalam tingkatan yang berbeda dan waktu yang lebih lambat.

Tetapi dengan kelebihannya, media mampu menyebarkan informasi lebih luas. Pembentukan kesan melalui media massa dinilai cukup efektif dan banyak digunakan oleh aktor politik untuk mempersuasi masyarakat. Media massa seperti televisi memiliki kelebihan seperti kontennya yang beragam, saluran audiovisual, bersifat domestik, dekat dan personal serta ada pengalaman keterlibatan (McQuaill 2011,40).

Beberapa aktor politik yang memiliki media sendiri seperti Abu Rizal Bakri, Surya Paloh, Hary Tanoe sangat mengeksplor medianya untuk pembentukan kesan. Hal ini cukup efektif hanya ditingkat awareness saja, karena masyarakat sekarang adalah masyarakat aktif mereka akan memproses apa yang dilihatnya di media dan membandingkannya dengan media lain, atau beberapa mereka yang telah melakukan komunikasi dan interaksi akan membandingkan, apakah sesuai apa yang terlihat di media sesuai dengan kesehariannya. Seperti disebutkan di atas, kelemahan dari pembentukan kesan melalui media ini adalah petunjuk non verbal kurang bisa terlihat dengan baik.

Setiap media memiliki kelebihan dan kelemahan, Jokowi dengan cara berbeda cukup melakukan apa yang menjadi kewajibannya sebagai pemimpin, dan berbagai media meliput kegiatannya sehingga mampu meningkatkan elektabilitasnya, terutama media yang berperan di sini adalah internet. Untuk beberapa hal internet mampu menjebatani masyakat untuk melakukan social movement. Di bawah ini akan dijelaskan tentang pola penggunaan internet dan social media dalam arena pemasaran politik. Lilleker (2011) menyatakan ada empat kecenderungan model campaign melalui internet, yaitu 1) informing, 2) engaging, 3) persuading, 4) mobilizing interacting (Nyarwi 2012). 
Internet sebagai media yang memberikan ruang kebebasan dalam memilih kepada para pengguna menjadi penentu bagi keterpilihan Jokowi. Internet berpusat pada "user" (pengguna). Pemaknaan atas konten internet berpusat pada pengguna. Tampaknya sosok Jokowi yang pro rakyat lebih banyak dikonstruksi lewat media online internet. Hal inilah yang menjadikan pemilik media mainstream sendiri juga tidak mampu menyaingi popularitas Jokowi di hadapan publik

\section{Impression Management J okowi}

Setiap individu memiliki karakter yang unik (dan aneh), mulai dari kebiasaan, kelakuan, kepercayaan, sikap, nilai, kemampuan, kebutuhan, ketertarikan, sejarah keluarga, dan sebagainya. Namun saat individu berinteraksi dengan orang lain, individu tidak dapat menunjukkan semua yang ada dalam wilayah public selfsehingga tanpa kita sadari, kita menunjukkan public self pada semua interaksi kita. Selain itu, melalui norma-norma sosial yang ada, individu membedakan karakter diri (self) mana yang pantas atau tidak untuk untuk konteks-konteks tertentu. Untuk membantu memahami area publik dan area privat, berikut ini bagannya:

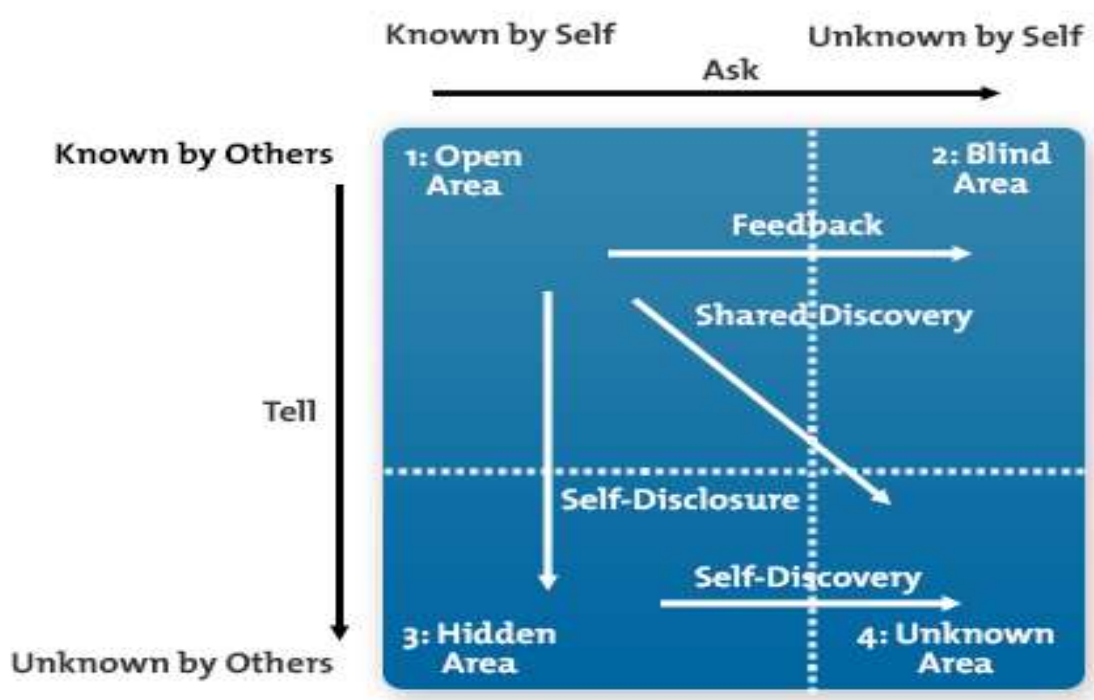


Impression Management-open area (pengelolaan public-self) inilah yang akan dibahas. Sebagai makhluk yang melakukan kegiatan sosial, kita sering peduli dengan image atau kesan yang kita tampilkan kepada orang lain (Piwinger and Ebert 2001). Sebagai individu, kita mampu mengatur dan mengelola apa yang akan kita tampilkan dalam diri kita, apa yang ada di depan ketika terjadi sebuah komunikasi atau yang oleh Erving Goffman (1956) disebut dengan front stage.

Front Stage inilah yang ingin ditampilkan di depan orang lain. Kita bisa mengatur apabila kita ingin dicitrakan tertentu dan didukung beberapa hal jika ingin menciptakan kesan tersebut. Pengaturan kesan bisa dilakukan dengan menambahkan atribut untuk menambahkan kesan yang akan diciptakan. Misalnya di awal kepemimpinan, Jokowi dicitrakan sebagai seseorang yang apa adanya dan sederhana maka dia menggunakan baju putih. Hal ini tidak hanya dilakukan oleh Jokowi tetapi banyak orang. Jika kita lihat orang-orang yang ingin mencalonkan diri sebagai anggota DPRD, mereka akan menggunakan baju putih agar dianggap bersih dan tidak korupsi. Jika mereka ingin dikesankan sebagai orang yang pintar, mereka akan menggunakan bahasa asing agar terlihat intelektual.

Sebagaimana konsep Erving Goffman, image yang coba ditampilkan dapat dianalogikan seperti seorang aktor yang sedang bermain peran. Seperti halnya seorang aktor, kita akan berusaha untuk menjadi peran tertentu, bahkan beberapa aktor yang profesional bisa memainkan peran apapun. Kita menggunakan satu set tingkah laku verbal dan non verbal dengan hati-hati untuk mencerminkan image tersebut.

Jokowi sebagai aktor politik juga melakukan apa yang digambarkan oleh Erving Goffman, memainkan perannya. Sebagai pemimpin yang baik dia harus mampu untuk menempatkan dirinya dan mengatur (manage) kesan yang akan diciptakannya. Hal ini terlihat di beberapa kesempatan yang diliput media. Ketika Jokowi bertemu dengan masyarakat dan melakukan kegiatan blusukan, dia menampilkan dirinya sebagai sosok yang ramah dan dekat dengan masyarakat, mendengarkan segala keluh kesah masyarakat. Ketika dia menampilkan dirinya sebagai seorang pemimpin, dia menjadi sosok yang tegas. Ketika blusukan dan melihat adanya kesalahan, seperti pegawai kecamatan 
yang datang terlambat, dia pun memberikan sanksi. Ketika Jokowi bertemu dengan SBY, dia menampilkan dirinya sebagai sosok yang 'manut' dan menghormati atasannya.

\section{Self- Presentation-Presentasi Diri}

Mead mendefinisikan diri (self) sebagai kemampuan untuk merefleksikan diri kita sendiri dari prespektif orang lain, membayangkan diri kita dilihat orang lain. Mead menyebut hal ini sebagai cermin diri (looking glass self) atau kemampuan diri kita melihat diri sendiri dalam pantulan orang lain (West and Lynn 2008, 106). Istilah presentasi diri dan strategi presentasi diri digunakan oleh Edward Jones dan rekannya untuk menggambarkan konsep manajemen kesan mereka. Teori presentasi diri didasarkan pada asumsi bahwa seseorang yang menghadirkan seperangkat perilaku selama interaksi akan memimpin orang lain untuk memastikan jenis atribusi tentang seseorang. Perilaku ini dan atribusi terkait telah diringkas menjadi sebuah tipologi dari lima jenis atribusi, strategi karakteristik yang harus mendatangkan atribusi, dan berbagai taktik untuk mengimplementasikan strategi tersebut:

1. Strategi Menjilat: digunakan untuk seseorang yang ingin dianggap menyenangkan atau ramah.

2. Strategi Self Promotion: digunakan untuk seseorang yang ingin dianggap berkualitas.

3. Strategi Contoh: digunakan untuk seseorang yang ingin dianggap sebagai contoh dan taktik seperti diam-diam menunjukkan kemampuannya, kompetensi, integritas, atau nilai-nilai daripada menyatakannya secara langsung kepada orang lain.

4. Strategi Permohonan: digunakan untuk seseorang yang ingin dianggap sebagai orang yang tak berdaya.

5. Strategi Intimidasi: digunakan oleh seseorang yang ingin dianggap sebagai orang yang kuat atau memiliki kendali (Baumeister 1987).

Dalam beberapa jenis strategi yang ada dalam Impression Management, Jokowi lebih menggunakan strategi contoh. Dia memberikan contoh kepada anak buahnya secara diam-diam agar mereka bisa meniru apa yang dilakukan oleh atasannya. Jokowi juga mencontohkan sebagai pemimpin yang baik 
sehingga banyak media yang memberitakan kegiatannya.

Jokowi memanfaatkan momentnya saat itu sebagai media darling sehingga menggunakan strategi self promotion agar dianggap berkualitas. Untuk mendukung hal tersebut Jokowi menggunakan media untuk meliput kegiatannya. Strategi ini cukup berhasil karena bisa kita lihat sampai saat ini pendukung setia Jokowi masih banyak.

Bagi seorang pemimpin pengelolaan kesan sangatlah diperlukan. Segala hal yang dilakukan pemimpin akan dikritisi oleh banyak pihak, baik yang pro ataupun kontra. Bahkan di beberapa negara didatangkan para pelatih pidato dan pengelolaan kesan bagi pemimpin. Ketika berhadapan dengan negara lain, para pemimpin negara ini menggunakan wajah publik, mewakili apa yang dipimpinnya. Keseriusan akan pentingnya hal ini bahkan difilmkan dalam 'King's Speech." Pemimpin yang baik harus bisa memainkan banyak peran, dan di sini apa yang dilakukan oleh Jokowi dalam memainkan perannya sebagai seorang pemimpin dinilai cukup berhasil. Jokowi mampu memasuki berbagai kalangan masyarakat, dia mampu berkomunikasi dengan anak muda melalui social medianya, berkomunikasi dengan masyarakat miskin terwujud dengan adanya kebijakan pro rakyat, serta berkomunikasi dengan lawan politiknya.

\section{Kedekatan Jokowi dengan Ormas Islam: Refleksi Kesan yang Unik Jokowi dan NU}

Jokowi sangat akrab dengan organisasi keislaman NU. Hal ini paling tidak terlihat dengan terpilihnya $\mathrm{KH}$. Ma'ruf Amin (KMA) sebagai calon wakil presiden (Hantoro 2018). Banyak orang yang meragukan KMA, baik secara fisik maupun kompetensi. KMA adalah seorang ulama yang dibesarkan dalam tradisi NU, berperan penting dalam tubuh NU dan juga MUI. la kemudian dipilih oleh Jokowi untuk menjadi wakilnya dalam pertarungan pemilihan presiden tahun 2019.

Apa yang dilakukan J okowi sejatinya tidak sulit untuk dibaca. Jokowi paham betul bahwa dirinya telah dikesankan anti-Islam oleh sekelompok Umat Islam yang tidak mendukungnya (Kuwado and Farisa 2018). Aksi 212 di Jakarta menggambarkan itu kepada publik bagaimana berjaraknya Jokowi dari 
kelompok Islam ini. Kesan inilah kemudian yang dimainkan oleh Jokowi. la pun menarik figur KMA untuk menjadi wakilnya sehingga perhatian umat Islam terpecah, dan secara spontan NU pun dengan upaya memperjuangkan tokoh mereka untuk menjadi wakil orang nomor satu di negeri ini.

Sekarang kedekatan J okowi dan NU bukan lagi rahasia umum. Kesan umum yang melekat pada benak banyak orang di Indonesia saat ini adalah bahwa Jokowi adalah bagian dari NU sebagai penyumbang suara terbesar untuk Jokowi. Di sisi lain, Jokowi berada pada titik aman dalam konteks Umat Islam di Indonesia, karena kedekatannya dengan ulama-ulama NU telah menjadi tameng berharga bagi nasib politik Jokowi. Hanya saja tantangan Jokowi adalah bagaimana kesan yang dibangunnya ini bisa aman di mata organisasi Islam lain seperti Muhammadiyah yang juga tidak kalah kontributif bagi sejarah perjalanan bangsa ini.

\section{Jokowi dan Sarung}

Jokowi dan sarung adalah suatu yang unik. Jokowi boleh dikatakan satusatu presiden Indonesia yang sangat percaya diri menggunakan sarung dalam setiap kesempatan kegiatan keagamaan. Kunjungannya ke beberapa tokoh ulama dan pesantren di Indonesia selalu ditandai dengan sarung yang dikenakannya (Saubani 2018). Sarung kemudian menjadi identitas dan kesan yang melekat pula pada Jokowi sebagai presiden yang suka bersarung (Prasetia 2019).

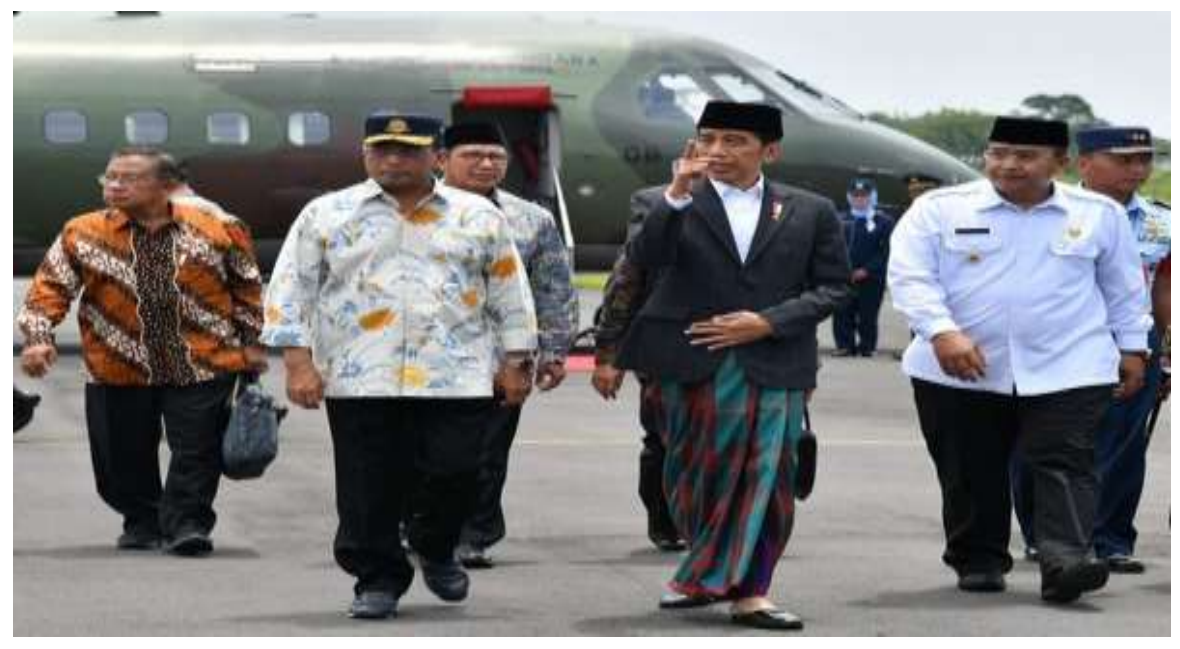


Di Indonesia, sarung adalah sebuah identitas kebudayaan khususnya bagi kalangan pesantren. Pesantren tradisional di Indonesia adalah pesantren dengan tradisi bersarung bagi para kiyai dan santri-santrinya. Potret kebudayaan inilah yang tampaknya ditangkap dengan baik oleh J okowi. J okowi melalui sarung cukup berhasil membangun citra dirinya sebagai seorang presiden yang dekat tradisi dan dunia pesantren. Masyarakat umum khususnya kalangan pesantren pun semakin terafirmasi dengan kesan yang ditampilkan Jokowi ini.

Namun, tradisi bersarung bagi seorang presiden sejatinya tidak lebih dari sekadar simbol komunikasi politik. Fakta menunjukkan, KMA yang awalnya seorang ulama yang sehari-harinya bersarung pun harus melepaskan sarungnya ketika menjadi wakil presiden untuk kegiatan-kegiatan formal kenegaraan. KMA berusaha menyesuaikan diri dengan konteks acara pemerintahan yang umumnya sangat resmi. la pun tidak lagi menampakkan identitas sarungnya dalam acara-acara publik kenegaraan, kecuali hanya acara tertentu saja. Hal ini membuktikan bahwa pilihan bersarung bagi seorang presiden atau calon presiden lebih merupakan kesan yang dikonstruksi secara tidak permanen.

\section{Jokowi dan Islam Nusantara}

Hal lain yang cukup unik adalah Jokowi dan Islam Nusantara. Islam Nusantara menjadi salah satu jargon yang disuarakan secara lantang oleh NU. Islam Nusantara merujuk pada pengalaman Islam yang terkolaborasi dengan dengan penuh hikmah dengan tradisi dan kebudayaan lokal Nusantara tanpa menghilangkan substansi dari Islam itu sendiri. Islam Nusantara adalah sesuatu yang menarik, dan semakin bertambah menariknya ketika terminologi ini didukung secara serius oleh Jokowi (Nashrillah 2015).

Jokowi dalam beberapa kesempatan pidatonya tentang keislaman, tidak jarang menyebut beberapa terminologi yang merujuk pada Islam Nusantara, seperti istilah Islam moderat dan rahmatan lil alamin (Ardianto 2018). Jokowi tampaknya sangat mengerti bahwa untuk membangun kedekatan dengan umat Islam lokal harus dengan mencitrakan diri sebagai tokoh yang pro konsep Islam Nusantara. Di sisi lain, kecenderungan Jokowi pada Islam Nusantara semakin menemukan relevansinya ketika ia didukung oleh tokoh-tokoh Islam 
yang sangat getol memperjuangkan Islam Nusantara. Ditambah lagi perlawanan terhadap Islam transnasional dan radikalisme sangat galak dilakukan di era kepresidenan Jokowi.

\section{Simpulan}

Dari paparan di atas dapat disimpulkan bahwa Jokowi adalah figur yang cukup berhasil membangun citra dirinya sebagai pilihan yang distingtif di mata masyarakat. Jokowi membangun suatu kesan yang berbeda dengan tampil sebagai sosok yang sederhana, tidak berlebihan, serta penuh kepedulian kepada rakyat. Kesan seperti ini jarang sekali dirasakan oleh masyarakat Indonesia selama bertahun-tahun berganti pemimpin. J okowi mampu memenangkan hati rakyat, meski ia harus berhadapan dengan kekuatan lain yang secara fisik dan materil jauh lebih unggul dari pada J okowi.

Di sisi lain dalam kesan yang dikonstruksi Jokowi, terdapat fakta unik dalam relasinya dengan Umat Islam. Jokowi hampir gagal merebut hati Umat Islam. Bahkan ia dianggap anti Islam. Di tengah isu itu, Jokowi mampu keluar menjadi pemenang dengan strategi yang tidak terduga. la meleburkan dirinya dalam kekuatan besar umat Islam di Indonesia, dalam hal ini organisasi NU. Hal ini terlihat dari pilihan Jokowi yang jatuh kepada KH. Ma'ruf Amin sebagai wakil presiden, serta kebiasannya menggunakan sarung dan pro Islam Nusantara.

\section{Referensi}

Andylala Waluyo. 2013. "Jokowi Raih Penghargaan Walikota Terbaik Ketiga Dunia." Voaindonesia.

Ardianto, Arif. 2018. "Beri Kuliah Umum di Malang, Presiden Jokowi Bahas Islam Nusantara." jatimnow.com. https://jatimnow.com/baca-1195-beri-kuliahumum-di-malang-presiden-jokowi-bahas-islam-nusantara.

Asch, S.E. 1946. "Forming Impressions of Personality." Journal of Abnormal and Social Psychology 41: 258-90.

Baumeister, Roy F. 1987. "Self-Presentation Theory: Self-Construction and Audience Pleasing." Springer Series in Social Psychology. Theories of Group Behavior.

Berger, Charles R, and Bradac James J. 1982. Language and Social Knowledge: Uncertainty in Interpersonal Relations. E. Arnold.

Carlston, D.E, and L Mae. 2000. "Impression Formation." Encyclopedia of Psychology 4.

Goffman, Erving. 1956. "Embarrassment and Social Organization." The American Journal of Sociology 62 (3): 264-71. https://doi.org/doi:10.1086/222003. 
Griffin, Em. 2012. A First Look At Communication Theory. New York: McGraw-Hill. Hantoro, Juli. 2018. “Jokowi Pilih Maruf Amin Sebagai Cawapres.” Kompas, 2018. https://nasional.tempo.co/read/1115535/jokowi-pilih-maruf-aminsebagai-cawapres.

Kuwado, Fabian Januarius, and Fitria Chusna Farisa. 2018. "Ini Alasan Jokowi Pilih Ma'ruf Amin Jadi Cawapresnya." Kompas.Com, 2018. https://nasional.kompas.com/read/2018/08/09/18381791/ini-alasanjokowi-pilih-maruf-amin-jadi-cawapresnya?page=all.

Littlejohn, Stephen. W Karen, A. Foss. 2009. "Encyclopedia of Communication Theory." In . Sage Publications.

Littlejohn, Stephen W., and Karen A. Foss. 2012. Teori Komunikasi 'Theories of Human Communication.'J akarta: Salemba Humanika.

McQuaill, Dannis. 2011. Teori Komunikasi Massa. Jakarta: Salemba Humanika.

Nashrillah, Faiz. 2015. “Jokowi Bicara Soal Beda Islam Di Indonesia Dan Timur Tengah." Tempo.Co, 2015. https://nasional.tempo.co/read/674930/jokowibicara-soal-beda-islam-di-indonesia-dan-timur-tengah.

Nyarwi, Ahmad. 2012. "From Mars Mediated-Political Marketing to Mixed Mediated-Political Marketing: The Rise of Social Media as Political Marketing Tools During the 2012 Governatorial Election of Special Region of Jakarta, Indonesia."

Piwinger, Manfred, and Helmut Ebert. 2001. "Impression Management: Wie Aus Niemand Jemand Wird." In Kommunikationsmanagement, edited by Guenther et al Bentele. Luchterhand, Neuwied.

Prasetia, Andhika. 2019. "Jokowi Ajak Masyarakat Pakai Sarung Minimal Sebulan Sekali." Detik.Com, 2019. https://news.detik.com/berita/d-4451939/jokowiajak-masyarakat-pakai-sarung-minimal-sebulan-sekali.

Saubani, Andri. 2018. "Mengenakan Sarung, Jokowi Blusukan Ke Ponpes-Ponpes Di Jatim." Republika, 2018. https://www.republika.co.id/berita/nasional/politik/pjx1w0409/mengenak an-sarung-jokowi-emblusukan-emke-ponpesponpes-di-jatim.

West, Richard, and H. Turner Lynn. 2008. Teori Komunikasi-Analisis Dan Aplikasi. Jakarta: Salemba Humanika. 